\title{
Epidermal Growth Factor Binding Sites on Human Erythrocytes in Donors With Different ABO Blood Groups
}

\author{
Bernd Engelmann, Udo Schumacher, and Ekkehard Haen \\ Physiologisches institut der Universität München, München (B.E.); Department of Human Morphology, University of Southampton, United \\ Kingdom (U.S.); and Walther Straub Institut für Pharmakologie und Toxikologie der Universität München (E.H.)
}

\begin{abstract}
Analysis of epidermal growth factor $\left({ }^{125} \mathrm{~J}\right.$-EGF) binding to human red cells revealed the presence of two classes of binding sites with apparent equilibrium dissociation constants (app. $K_{d}$ ) in the $10^{-10}-10^{-9} \mathrm{M}$ and in the $10^{-8} \mathrm{M}$ range, respectively. The number of binding sites/cell ranged between 600 and 2,400 for the high-affinity binding site and between 7,200 and 23,000 for the low-affinity site. No differences were seen in the apparent $K_{d}$ values for both types of binding sites between red cells obtained from donors with different ABO-blood groups. An increase in the number of high affinity EGF binding sites was observed in donors with blood group $A_{1}$-erythrocytes as compared to red cells taken from donors with blood groups $O$ and $B$.
\end{abstract}

Key words: epidermal growth factor (EGF) binding, human erythrocytes, ABO blood groups

\section{INTRODUCTION}

Binding sites for the epidermal growth factor (EGF) have been described for a great variety of different cell types (for a review see [1]). Specific binding to plasma cell membranes is thought to be due to interaction of the growth factor with its receptor, a $170 \mathrm{kDa}$ membrane protein whose structure has been studied in great detail especially in A 431 cells [1]. The extracellular portion of the EGF receptor contains several oligosaccharide chains which, at least in the case of A 431 cells, has been shown to contain terminal blood group A antigen-like sugar residues $[2,3]$. A recent study indicates that modification of these terminal sugar residues may alter both interaction of EGF with its high affinity binding site as well as the kinase activity of the receptor [4].

The detection of the presence of binding sites for EGF on human erythrocytes (see Results) prompted us to investigate the ABO-blood group dependence of EGF binding to these cells. Several human red cell membrane proteins and membrane lipids are known to bear oligosaccharide chains with $\mathrm{ABH}$-antigen-like properties [5]. We hypothesized that, in analogy to the EGF receptor of A 431 cells, the putative EGF receptor of human erythrocytes might well be equipped with $\mathrm{ABH}$-antigen-like sugar residues. Since erythrocytes with different ABHantigens are believed to differ only in the composition of the protein and lipid attached sugar chains, donors with different $\mathrm{ABO}$-blood groups may serve as "biological variants" for the study of the influence of $\mathrm{ABH}$-antigens on binding of EGF to these cells.

\section{MATERIALS AND METHODS}

Venous blood anticoagulated by heparin was drawn from apparently healthy donors. Red cells were washed four times with $10 \mathrm{vol}$ of a solution containing $140 \mathrm{mM}$ $\mathrm{NaCl}, 5 \mathrm{mM} \mathrm{KCl}, 5 \mathrm{mM}$ glycylglycine, $5 \mathrm{mM}$ glucose, $0.2 \mathrm{mM} \mathrm{MgCl}_{2}, 1.25 \mathrm{mM} \mathrm{CaCl}_{2}(\mathrm{pH} 7.55)$, referred to as $\mathrm{Na}$ buffer throughout.

Cells were counted under a light microscope (Neubauer chamber); $50 \mu$ lof packed red cells were incubated (in triplicates) for $3 \mathrm{hr}$ at $4^{\circ} \mathrm{C}$ with 12 concentrations of

${ }^{125}$ I-EGF (Amersham-Buchler, Braunschweig, Germany, specific activity $0.76 \mathrm{Ci} / \mathrm{mmol}$ ) in the range between $1.0 \times 10^{-9}-2 \times 10^{-7} \mathrm{M}$, the total reaction volume amounting to $500 \mu \mathrm{l}$. The reaction was started by manual addition of the red cell suspension and stopped by centrifugation for $10 \mathrm{~min}$ at $10,000 \mathrm{~g}$ in an Eppendorf-Hermle

Received for publication May 20, 1991; accepted August 15, 1991.

Address reprint requests to Dr. B. Engelmann at Physiologisches Institut der Universität München, Pettenkoferstrasse 12, 8000, Munich 2, West Germany. 
centrifuge Model Z 380 (Eppendorf, Hamburg, Germany). Cells were quickly washed three times at $4^{\circ} \mathrm{C}$ with ice-cold Na buffer. Radioactivity of the pellets (total binding) was assessed by gamma-counting. Unspecific binding as determined in the presence of an excess of unlabelled EGF $\left(1.6 \times 10^{-6} \mathrm{M}\right)$ was found to be less than $30 \%$ of total binding for both types of binding sites. Pipetting was performed by a Tecan Robotic Sample processor Model 5052 (dual arm system, Tecan AG, Frankfurt, Germany) as described in [6]. For all experiments given in Results the following binding equation for two independent classes of binding sites [7] was fitted to the data by nonlinear regression analysis yielding estimates of the binding parameters for a high- and a lowaffinity binding site.

$$
c_{b}=\frac{B_{m 1} \times c_{f}}{K_{d 1}+c_{f}}+\frac{B_{m 2} \times c_{f}}{K_{d 2}+c_{f}}+C \times c_{f},
$$

where $\mathrm{B}_{\mathrm{m} 1}, \mathrm{~K}_{\mathrm{dl}}$ are the high-affinity binding site parameters, $B_{m 2}, K_{d 2}$ are the low-affinity binding site parameters, $c_{f}, c_{b}$ are free and bound concentration of ligand, and $\mathrm{C}$ is the constant (correcting for unspecific binding). The above equation gives an estimate of the specific binding of a ligand to two independent binding sites (first two terms on the right side of the equation). The constant $\mathrm{C}$ is used to correct for any linear portion of total binding (indicative of unspecific binding) remaining after fitting the data to the parameters for two saturating binding curves.

\section{RESULTS}

Nonlinear regression analysis revealed the presence of two types of binding sites for the epidermal growth factor (EGF) on human erythrocytes (Fig. 1): a high-affinity binding site with an apparent equilibrium dissociation constant in the $10^{-10}-10^{-9} \mathrm{M}$ range $\left(0.2-4.3 \times 10^{-9} \mathrm{M}\right)$ and about 1,000 sites/cell $(580-2,400)$ and a low-affinity binding site with an apparent equilibrium dissociation constant in the $10^{-8} \mathrm{M}$ range $\left(1.8-5.7 \times 10^{-8} \mathrm{M}\right)$ and around 10,000 sites/cell $(7,200-23,000)$.

No considerable differences in app. $K_{d}$ values were observed between donors with different ABO-blood groups for both types of binding sites. $A_{1}$ erythrocytes exhibited a higher number of binding sites for EGF as compared to red cells taken from individuals with blood groups $\mathrm{O}$ and $\mathrm{B}$ (Tab. I), the increase being more prominent for the high affinity binding site (Tab. I).

\section{DISCUSSION}

The results of the present study indicate that human red cells bear two (hitherto unknown) classes of independent binding sites for epidermal growth factor (EGF), in ac-
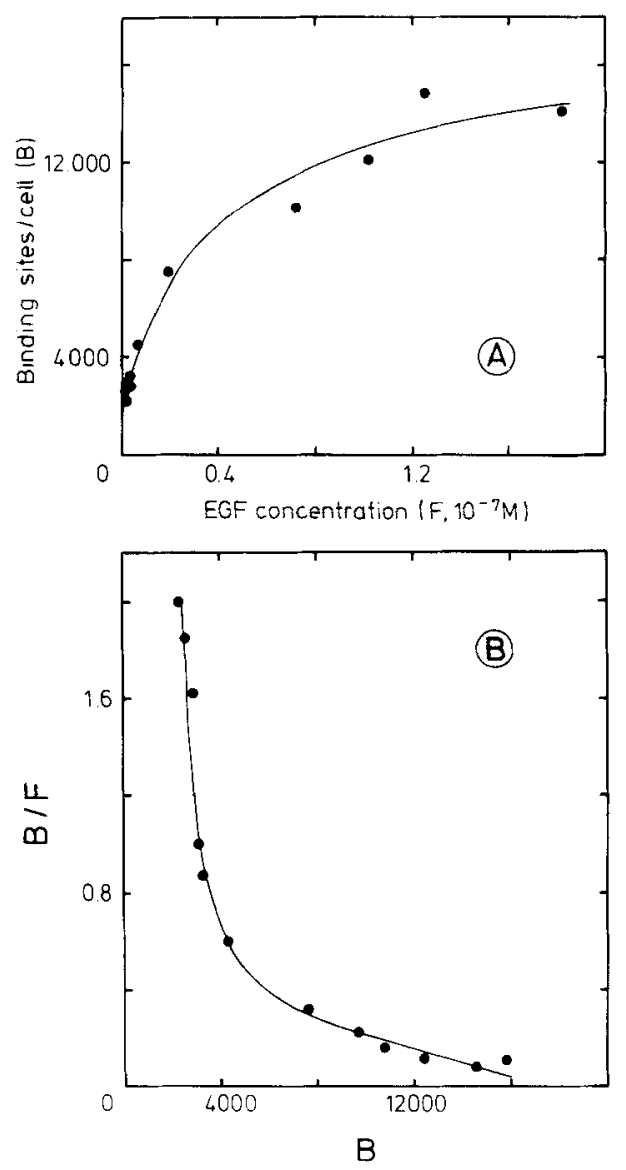

Fig. 1. Binding isotherm for the binding of ${ }^{125}$-EGF to human red blood cells in a concentration range between $1.0 \times$ $10^{-9}$ and $2 \times 10^{-7} \mathrm{M}$. A: Direct plot of the binding data. B: Scatchard plot: A mathematical model of two classes of saturable binding sites was iteratively fitted to the binding data. The position of the data suggests two classes of independent binding sites (high- and low-affinity binding).

cordance with results obtained on several other cell types [1]. A recent report indicates that the most abundant membrane protein present in human erythrocytes, the band 3 protein, is a fairly good substrate for the EGF receptor associated tyrosine kinase [8]. In addition, we observed in human erythrocytes a Ca inward transport susceptible towards inhibition by the phorbol ester TPA [9]. Thus, there is both direct and indirect evidence that EGF elicits intracellular responses in human erythrocytes.

The EGF receptor of A 431 cells has been shown to bear $\mathrm{ABH}$-blood group antigen-like sugar structures $[2,3]$ which may influence binding of the growth factor to its receptor [4]. In the study of Defize et al. [4], the lack of blood group antigen A on A431 cells was associated with an increased number of high affinity receptors for EGF. In contrast, in the present study, the amount of highaffinity binding sites for EGF on human erythrocytes was higher in blood group $\mathrm{A}_{1}$ as compared to blood group $\mathrm{B}$ and $\mathrm{O}$ erythrocytes (Table I). However, observations re- 
TABLE I. EGF Binding to Erythrocytes of Healthy Donors With Different ABO Blood Groups*

\begin{tabular}{|c|c|c|c|c|}
\hline \multirow[b]{3}{*}{ Blood group } & \multicolumn{4}{|c|}{ EGF binding } \\
\hline & \multicolumn{2}{|c|}{ High-affinity site } & \multicolumn{2}{|c|}{ Low-affinity site } \\
\hline & $B_{\max }$ & $\begin{array}{c}\text { app. } K_{d} \\
\left(10^{-9} \mathrm{M}\right)\end{array}$ & $\mathrm{B}_{\max }$ & $\begin{array}{c}\text { app. } K_{d} \\
\left(10^{-8} \mathrm{M}\right) \\
\end{array}$ \\
\hline $0_{(n=6)}$ & $960 \pm 680$ & $1.7 \pm 1.2$ & $10,900 \pm 5,200$ & $4.3 \pm 1.3$ \\
\hline $\begin{array}{l}\mathrm{A}_{1} \\
\quad(\mathrm{n}=4)\end{array}$ & $1,830 \pm 900$ & $1.5 \pm 2.0$ & $14,700 \pm 5,600$ & $3.7 \pm 1.6$ \\
\hline B $(n=3)$ & $950 \pm 390$ & $1.3 \pm 0.3$ & $10,500 \pm 8,500$ & $4.2 \pm 2.2$ \\
\hline
\end{tabular}

lated to the presence of blood group antigen A in A431 cells are not strictly comparable to those obtained on blood group A containing human red blood cells. It is known, for example, that there are differences in the structure of the antigen A containing oligosaccharide chains (type 1A in A431 cells [2] as compared to type 2A in human red blood cells [11]) which could influence the binding of EGF.

The EGF receptors of several other cell types do not appear to be glycosylated with $\mathrm{ABH}$ determinants $[2,10]$. However, these cell types (fibroblasts, Swiss $3 \mathrm{~T} 3$ cells, and human placenta) are not known to contain $\mathrm{ABH}$ antigen-like sugar structures on the proteins of their plasma membranes. In contrast, human erythrocytes are well known to bear these oligosaccharides on membrane proteins [5]. The preliminary data presented in Table I indicate that in erythrocytes of blood group $\mathrm{A}_{1}$ donors higher number of EGF binding sites are present. The simplest explanation of these results would be that the different $\mathrm{ABH}$-antigens present on a hitherto not demonstrated EGF receptor of human erythrocytes might influence the binding of EGF. Alternatively, $A B H$ antigens present on red cell glycoproteins or glycolipids in close vicinity to the EGF binding site could modulate the interaction of EGF with its binding site.

Since only a low number of donors have been analyzed in the present investigation, the results require confirmation from studies performed on larger populations. Furthermore, it should also be investigated in future studies whether human red cells contain EGF receptors similar to those of other cell types (e.g., by immunoprecipitation of the phosphorylated receptor). Such experiments will be of particular importance in view of previous observations indicating that cells of the human hematopoietic system do not appear to express the EGF receptor [1].

\section{ACKNOWLEDGMENTS}

The technical assistance of S. Eckermann and $\mathrm{H}$. Schairer is gratefully acknowledged. We thank the
Wilhelm Sander-Stiftung for financial support (grant 89.039.1 to U.S.).

\section{REFERENCES}

1. Carpenter G: Receptors for epidermal growth factor and other polypeptide mitogens. Ann Rev Biochem 56:881-914, 1987.

2. Fredman P, Richert ND, Magnani JL, Willingham MC, Pastan I, Ginsburg V: A monoclonal antibody that precipitates the glycoprotein receptor for epidermal growth factor is directed against the human blood group $H$ type 1 antigen. J Biol Chem 258:11206-11210, 1983.

3. Childs RA, Gregoriou M, Scudder P, Thorpe SJ, Rees AR, Feizi T: Blood group-active carbohydrate chains on the receptor for epidermal growth factor of A431 cells. EMBO J 3:2227-2233, 1984.

4. Defize LHK, Arndt-Jovin DJ, Jovin TM, Boonstra J, Meisenhelder J, Hunter T, de Hey HT, de Laat SW: A431 cell variants lacking the blood group $A$ antigen display increased high affinity epidermal growth factor receptor number, protein-tyrosine kinase activity, and receptor turnover. J Cell Biol 107:939-949, 1988.

5. Hakomori S: Blood group ABH and Ii antigens of human erythrocytes: Chemistry, polymorphism, and their developmental change. Sem Hematol 18:39-62, 1981.

6. Haen E, Liebl B, Lederer T, Pliska V: Revised radioreceptor assay for $\beta_{2}$-adrenoreceptors expressed on peripheral mononuclear leukocytes. J Rec Res 11:129-140, 1991.

7. Sandnes D, Waelgaard J, Jacobsen S: Modes of determining $\beta$-adrenoceptor number in human mononuclear leukocytes. Pharmcol Toxicol 61:265-270, 1987.

8. Shiba T, Akiyama T, Kadowaki T, Fukami Y, Tsuji T, Osawa T, Kasuga M, Takaku F: Purified tyrosine kinases, the EGF receptor kinase and the SRC kinase, can catalyze the phosphorylation of the band 3 protein from human erythrocytes. Bioch Biophys Res Comm $135: 720-727,1986$

9. Engelmann B, Haen E, Duhm J: Stimulation of $\mathrm{Ca}^{++}$uptake by epidermal growth factor in human erythrocytes is probably mediated by reversed $\mathrm{Na}^{+}-\mathrm{Ca}^{++}$exchange. Pflüg Arch 418:R117, 1991.

10. Parker PJ, Young S, Gullick WJ, Mayes ELV, Bennett P, Waterfield MD: Monoclonal antibodies against the human epidermal growth factor receptor from A431 cells. J Biol Chem 259:9906-9912, 1984.

11. Watkins WM, Greenwell P, Yates AD, Johnson PH: Regulation of expression of carbohydrate blood group antigens. Biochimie 70:1597$1611,1988$. 